\title{
Regulation of pregnancy-associated plasma protein A2 (PAPPA2) in a human placental trophoblast cell line (BeWo)
}

Pamela K Wagner, Aki Otomo and Julian K Christians ${ }^{*}$

\begin{abstract}
Background: Pregnancy-associated plasma protein A2 (PAPPA2) is an insulin-like growth factor-binding protein (IGFBP) protease expressed at high levels in the placenta and upregulated in pregnancies complicated by preeclampsia and HELLP (Hemolytic anemia, Elevated Liver enzymes, and Low Platelet count) syndrome. However, it is unclear whether elevated PAPPA2 expression causes abnormal placental development, or whether upregulation compensates for placental pathology. In the present study, we investigate whether PAPPA2 expression is affected by hypoxia, oxidative stress, syncytialization factors or substances known to affect the expression of PAPPA2's paralogue, PAPPA.

Methods: BeWo cells, a model of placental trophoblasts, were treated with one of the following: hypoxia $(2 \% \mathrm{O} 2)$, oxidative stress (20 microM hydrogen peroxide), forskolin (10 microM and 100 microM), TGF-beta (10 and $50 \mathrm{ng} / \mathrm{mL}$ ), TNF-alpha (100 ng/mL), IL-1 beta (100 ng/mL) or PGE2 (1 microM). We used quantitative RT-PCR (qRT-PCR) to quantify the mRNA levels of PAPPA2, as well as those of PAPPA and ADAM12 since these proteases have similar substrates and are also highly expressed in the placenta. Where we observed significant effects on PAPPA2 mRNA levels, we tested for effects at the protein level using an in-cell Western assay.

Results: Hypoxia, but not oxidative stress, caused a 47-fold increase in PAPPA2 mRNA expression, while TNF-alpha resulted in a 6-fold increase, and both of these effects were confirmed at the protein level. PGE2 resulted in a 14-fold upregulation of PAPPA2 mRNA but this was not reflected at the protein level. Forskolin, TGF-beta and IL-1 beta had no significant effect on PAPPA2 mRNA expression. We observed no effects of any treatment on PAPPA or ADAM12 expression.

Conclusion: Our study demonstrates that factors previously known to be highly expressed in preeclamptic placentae (PGE2 and TNF-alpha), contribute to the upregulation of PAPPA2. Hypoxia, known to occur in preeclamptic placentae, also increased PAPPA2 expression. These results are consistent with the hypothesis that PAPPA2 is upregulated as a consequence of placental pathology, rather than elevated PAPPA2 levels being a cause of preeclampsia.
\end{abstract}

\section{Background}

Preeclampsia affects approximately 1 in 15 pregnancies [1] and is characterized by a sudden rise in blood pressure and proteinuria which resolves after delivery [2,3]. Currently, there is no effective treatment for preeclampsia other than to induce delivery. However, premature delivery elevates the risk of neonatal death and health problems

\footnotetext{
* Correspondence: julian_christians@sfu.ca
Simon Fraser University, Biological Sciences, 8888 University Drive, Burnaby,

* Correspondence: julian_christians@sfu.ca
Simon Fraser University, Biological Sciences, 8888 University Drive, Burnaby, BC, V5A 156, Canada
}

(c) 2011 Wagner et al; licensee BioMed Central Ltd. This is an Open Access article distributed under the terms of the Creative Commons Attribution License (http://creativecommons.org/licenses/by/2.0), which permits unrestricted use, distribution, and reproduction in any medium, provided the original work is properly cited.

later in life [3-5]. The etiology of preeclampsia is thought to involve abnormal placental development [6-8].

Numerous studies have attempted to elucidate the mechanisms underlying abnormal placental development using microarrays to identify genes differentially expressed between placentae from healthy and complicated pregnancies $[9,10]$. Five studies have shown that placental expression of pregnancy-associated plasma protein A2 (PAPPA2) is upregulated at delivery in preeclampsia or a complication of preeclampsia, HELLP (Hemolytic anemia, Elevated Liver enzymes, and Low 
Platelet count) syndrome [9,11-14]. PAPPA2 is an insulin-like growth factor-binding protein (IGFBP) protease [15] expressed at high levels during pregnancy $[16,17]$ which shares approximately $40 \%$ amino acid similarity with PAPPA [15]. Abnormally low PAPPA levels in first trimester maternal circulation are associated with increased risk of preeclampsia [18,19], a pattern also observed for another IGFBP protease, ADAM12 [19-23].

It is not known whether altered PAPPA2 expression causes preeclampsia or is a response to placental pathology. It has been hypothesized that the upregulation of PAPPA2 in preeclamptic pregnancies is a compensatory response to abnormal placentation which might increase IGF availability and promote feto-placental growth [18]. A number of factors might trigger this upregulation, and in the present study we attempt to identify factors that regulate PAPPA2 expression.

Early placental development takes place in a low-oxygen environment [24], but impaired invasion into the decidua is thought to lead to even lower oxygen levels (hypoxia) in preeclampsia [1,10,25-27], which we hypothesize could upregulate PAPPA2. Ischemia-reperfusion injury might also occur due to intermittent blood flow into the intervillous spaces of the placenta [28], leading to the formation of damaging reactive oxygen species (ROS); this oxidative stress can be mimicked by peroxides [25,28,29].

It has been suggested that improper trophoblast cell fusion, or syncytialization, may be a cause of preeclampsia [6]. Since PAPPA2 is expressed in the syncytiotrophoblast $[14,17]$, we hypothesize that factors that affect syncytialization [30-32] will affect PAPPA2 expression.

The paralog of PAPPA2, PAPPA, is upregulated by TNF- $\alpha$, TGF- $\beta, \mathrm{PGE}_{2}$, and IL- $1 \beta$ in osteoblasts [33], and we predict that these factors may also regulate PAPPA2 expression, given the homology between PAPPA and PAPPA2.

The goal of the present study was to test our hypotheses regarding the regulation of PAPPA2 using BeWo cells as a model of placental trophoblasts $[34,35]$. In addition to PAPPA2, we also measured levels of PAPPA and ADAM12 since they are also placental IGFBP proteases $[21,36]$ associated with preeclampsia and intrauterine growth restriction (IUGR) [19,22,23,37,38], and IGFBP proteases may be coregulated [39]. We also measured levels of E-cadherin mRNA to determine the level of syncytialization, since E-cadherin expression decreases as cells fuse [40].

\section{Methods}

\section{Cell culture and materials}

BeWo cells, a gift from Dr. Andrée Gruslin of the University of Ottawa, were cultured in Ham's F-12K medium (Sigma Aldrich, St. Louis, MO) supplemented with $10 \%$ fetal bovine serum, $2 \mathrm{mM}$ L-glutamine,
$100 \mathrm{U} / \mathrm{mL}$ penicillin and $100 \mathrm{U} / \mathrm{mL}$ streptomycin in $5 \%$ $\mathrm{CO}_{2}$ and $95 \%$ air at $37^{\circ} \mathrm{C}$. Cells were used at passages 30-42. Porcine TGF- $\beta$, recombinant TNF- $\alpha$, and recombinant IL-1 $\beta$ were purchased from R\&D Systems (Minneapolis, $\mathrm{MN}$ ), forskolin and $\mathrm{PGE}_{2}$ were purchased from Sigma (St. Louis, MO), and $3 \% \mathrm{w} / \mathrm{v} \mathrm{H}_{2} \mathrm{O}_{2}$ was purchased from Anachemia (Lachine, Quebec).

\section{Experimental treatments}

For the hypoxic treatment, cells were cultured in $9 \mathrm{~cm}$ plates at $30 \%$ confluence and were maintained at $37^{\circ} \mathrm{C}$ in $5 \% \mathrm{CO}_{2}$ and $95 \%$ air (normoxia) for $24 \mathrm{~h}$, at which time the cells had reached $50 \%$ confluence. Half of the plates $(\mathrm{N}=5)$ remained under normoxic conditions while the other half were transferred to a chamber with an atmosphere of $93 \% \mathrm{~N}_{2}, 5 \% \mathrm{CO}_{2}$, and $2 \% \mathrm{O}_{2}$, as used previously to simulate hypoxia during preeclampsia $[31,41,42]$. These plates were incubated for a further $24 \mathrm{~h}$ before protein analysis or collection for RNA isolation.

For the growth factor and peroxide treatments, cells were cultured under normoxic conditions as described above for $24 \mathrm{~h}$. The medium was then replaced with fresh medium (control samples) or medium containing $\mathrm{H}_{2} \mathrm{O}_{2}$ at $20 \mu \mathrm{M}$ [29] or one of the following factors previously shown to upregulate PAPPA in osteoblasts cells: TGF- $\beta$ (10 ng/mL and $50 \mathrm{ng} / \mathrm{mL})$, TNF- $\alpha(100 \mathrm{ng} / \mathrm{mL})$ IL-1 $\beta$ (100 ng/mL), prostaglandin $E_{2}(1 \mu \mathrm{M})$, forskolin (10 $\mu \mathrm{M}$ and $100 \mu \mathrm{M}$, each dissolved in $0.1 \%$ ethanol) or a forskolin control (medium with $0.1 \%$ ethanol only) $[30,32,33,43](\mathrm{N}=5$ plates per treatment).

\section{Cell counting}

BeWo cells were cultured on 6-well plates for 24 hours, with the treatments described above. $2 \mu \mathrm{L}$ of Hoechst 33342 (Invitrogen, Carlsbad, CA) was added (final concentration of $1.5 \mu \mathrm{g} / \mathrm{mL}$ ), and the plates were incubated for 20 minutes at $37^{\circ} \mathrm{C}$. The medium was then replaced with $2 \mathrm{~mL}$ of Hank's buffered salt solution (HBSS). Five pictures were taken of each well at 10x magnification, and cells were counted using Image software (NIH). Each experiment was repeated three times.

\section{RNA isolation and RT-PCR}

BeWo cells were collected and homogenized in $600 \mu \mathrm{L}$ of buffer RLT (Qiagen, Ontario, Canada) using pipetting and Qiashredders (Qiagen, Ontario, Canada) and total RNA was extracted using the RNeasy Mini kit (Qiagen, Ontario, Canada) according to the manufacturer's instructions. RNA concentration was determined using a Nanodrop spectrophotometer (Thermo Fischer Scientific Inc. Waltham, MA), and each sample was diluted to a final concentration of $50 \mathrm{ng} / \mu \mathrm{L}$. Reference samples were made by combining $50 \mu \mathrm{L}$ from each sample. These reference samples were measured for each gene and 
were included in every assay to account for variation between assays. Quantitative reverse transcriptase PCR (qRT-PCR) was performed to compare levels of PAPPA2, PAPPA, ADAM12, and E-cadherin mRNA. Levels of $\beta$-actin [31] and GAPDH [44] were also measured and used to standardize the values of the other genes (see Table 1 for primer sequences). The qScript one-step SYBR green qRT-PCR kit (Quanta Biosciences Inc. Gaithersburg, MD) was used to reverse-transcribe and amplify each sample. Reverse transcription was carried out at $50^{\circ} \mathrm{C}$ for 30 minutes, followed by a PCR activation step of $95^{\circ} \mathrm{C}$ for 15 minutes, followed by amplification by 40 cycles of 1 minute at $94^{\circ} \mathrm{C}, 1$ minute at either $50^{\circ} \mathrm{C}, 56^{\circ} \mathrm{C}$ or $60^{\circ} \mathrm{C}$ (see Table 1 for annealing temperatures for each gene), and 1 minute at $72^{\circ} \mathrm{C}$, and a final extension of 10 minutes at $72^{\circ} \mathrm{C}$. Each reaction was performed using a volume of $25 \mu \mathrm{L}$ and contained $12.5 \mu \mathrm{L}$ of reaction mix, $8.5 \mu \mathrm{L}$ of RNA sample at $50 \mathrm{ng} / \mu \mathrm{L}, 1.5 \mu \mathrm{L}(22.5 \mathrm{mM})$ of each forward and reverse primer, $0.5 \mu \mathrm{L}$ of reverse transcriptase, and $0.5 \mu \mathrm{L}$ of nuclease free water. $\mathrm{Ct}$ values were recorded for each gene, defined as the point at which the signal crossed a predetermined threshold. Each sample was measured in triplicate and in each assay, one negative control and one reference sample were included for each gene. For each gene, we performed a melting curve analysis, and the qRT-PCR products were run on a $1 \%$ agarose gel to ensure that only one amplicon of the expected size was present.

\section{In-cell Westerns}

In-cell Westerns, an immunocytochemical assay to quantify proteins in fixed cells [45], were performed for treatments which had a significant effect on PAPPA2 mRNA levels $\left(2 \% \mathrm{O}_{2}, 1 \mu \mathrm{M} \mathrm{PGE}_{2}, 100 \mathrm{ng} / \mathrm{mL}\right.$ TNF- $\left.\alpha\right)$. Cells were cultured on 6-well plates, and treatments were performed as described above, using three wells per treatment $(\mathrm{N}=3)$. Following treatment, the medium was removed, and the cells were fixed in $2.4 \mathrm{~mL}$ of $3.7 \%$ formaldehyde in PBS for $20 \mathrm{~min}$. The cells were then permeabilized by washing with $3.2 \mathrm{~mL}$ PBS containing $0.1 \%$ Triton X-100 (Sigma Aldrich, St. Louis, MO) 5 times for 5 minutes each, with gentle shaking. The cells were blocked using $2.4 \mathrm{~mL}$ of near infrared blocking buffer (Rockland,
Gilbertsville, PA) for $1.5 \mathrm{~h}$ with gentle shaking. The cells were then incubated overnight at $4^{\circ} \mathrm{C}$ with 1:200 goat antihuman PAPPA2 polyclonal (AF1668; R\&D Systems, Minneapolis, MN) and 1:200 mouse anti-tubulin (T9026, Sigma, St Louis, MO) antibodies diluted in blocking buffer (Li-Cor Biosciences, Lincoln, NE) and 0.1\% Tween-20 (Sigma, ON, Canada) with gentle shaking, followed by 5 washes with PBS and $0.1 \%$ Tween-20 for 5 minutes per wash. Incubation with the secondary antibodies was carried out using a solution containing 1:800 fluorescently-labelled IRDye 800 donkey anti-goat and IRDye 680 donkey anti-mouse secondary antibodies (Li-Cor Biosciences, Lincoln, NE) diluted in Odyssey Blocking Buffer and $0.1 \%$ Tween-20 for $1 \mathrm{~h}$ in the dark with gentle shaking. We performed 5 more 5 minute washes with PBS in the dark to prevent breakdown of the IR dye. All steps except for primary antibody incubations were performed at room temperature. Two negative controls were included, one omitting each primary antibody. Preliminary work showed that the PAPPA2 and tubulin signals were above negative controls under control conditions. We used tubulin to standardize the amount of cells in each well because we were unable to detect a strong signal using an anti-actin antibody (CLT9001; Cedarlane, Burlington $\mathrm{ON}$ ). The intensity of staining in cells was quantified by densitometry using an Odyssey infrared imaging system (Li-Cor Biosciences).

\section{Western Blot}

Cell cultured medium was centrifuged to remove cellular debris, and $40 \mu \mathrm{L}$ was mixed with $5 x$ SDS loading buffer and heated for 10 minutes at $100^{\circ} \mathrm{C}$. Samples were run for 60 minutes through a $4 \%$ stacking and $8 \%$ separating polyacrylamide gel. After transfer, nitrocellulose membranes were blocked for 1 hour at room temperature in infrared blocking buffer, then incubated in 1:500 polyclonal goat anti-human PAPPA2 antibody diluted in the same blocking buffer, with $0.1 \%$ Tween-20. Membranes were washed 4 times in filter-sterilized PBS containing 0.1\% Tween-20 at room temperature, and incubated in a solution containing 1:10000 fluorescently-labelled IRDye 800 secondary antibody diluted in blocking buffer, $0.1 \%$ Tween-20 and $0.1 \%$ SDS for 45 minutes in the dark with gentle shaking. The membranes were again washed 4 times for 5 minutes

Table 1 Primer and probe sequences used in qRT-PCR for PAPPA2, PAPPA, ADAM12, E-cadherin, $\beta$-actin and GAPDH

\begin{tabular}{|c|c|c|c|c|}
\hline Gene & Forward Primer & Reverse Primer & Annealing Temperature & Source \\
\hline PAPPA2 & ACTCACCCAAGAGGGCATACATGA & GCACTGAGCTGGCAAAGTAGATGT & $50^{\circ} \mathrm{C}$ & This paper \\
\hline PAPPA & GTCATCTITGCCTGGAAGGGAGAA & AGGGCTGTTCAACATCAGGATGAC & $56^{\circ} \mathrm{C}$ & This paper \\
\hline ADAM12 & CTGGGCCACAATTTCGGGATGAAT & ACTGCTGAACACCATGGGAAATGG & $50^{\circ} \mathrm{C}$ & This paper \\
\hline E-cadherin & AGCCTCTGGATAGAGAACGCATTG & GGGTGAATTCGGGCTTGTTGTCAT & $50^{\circ} \mathrm{C}$ & This paper \\
\hline$\beta$-actin & GCGAGAAGATGACCCAGGATC & CCAGTGGTACGGCCAGAGG & $60^{\circ} \mathrm{C}$ & Knerr et al. (2005) [31] \\
\hline GAPDH & CGGGAAGCTTGTGATCAATGG & GGCAGTGATGGCATGGACTG & $56^{\circ} \mathrm{C}$ & Kudo et al. (2003) [30] \\
\hline
\end{tabular}


each in filter-sterilized PBS containing 0.1\% Tween-20 at room temperature, rinsed with filtered PBS, and scanned with an Odyssey infrared imaging system.

\section{Statistical analyses}

We used the method of Pfaffl [46] to calculate mRNA expression levels for PAPPA2, PAPPA, ADAM12, and Ecadherin, relative to the reference sample described above. For example, a value of 2 indicates a sample has 2 times more transcript than the reference sample, correcting for GAPDH or $\beta$-actin. qRT-PCR data were analysed using Wilcoxon signed-rank tests in JMP, Version 7 (SAS Institute Inc., Cary, NC). Results were normalized to $\beta$-actin or GAPDH.

\section{Results and Discussion}

BeWo cells express PAPPA2, with Ct values of approximately 25 and signal above the no-primary negative control in in-cell Western analysis. We examined the mRNA levels of PAPPA2, PAPPA, ADAM12 and E-cadherin in BeWo cells treated with different factors known to be involved in preeclampsia or shown to upregulate PAPPA. GAPDH and $\beta$-actin mRNA levels were used to normalize the mRNA levels of the other genes. However, GAPDH has been shown to increase under hypoxia [47], so only $\beta$-actin was used for hypoxia. The mRNA levels of $\beta$-actin and GAPDH did not differ significantly between treatments, suggesting that they were appropriate for use as controls. When used to standardize mRNA levels, $\beta$-actin and GAPDH produced similar results.

Hoechst 33342 staining was used to assess the number of BeWo cells under each treatment. Cells with condensed staining were considered dead, whereas cells with diffuse signal were considered alive. We did not find any significant cell death between treatments, when counting either the proportion or absolute number of alive and dead cells, which is consistent with previous studies [29,31].

\section{Hypoxia and oxidative stress}

Hypoxia has previously been shown to upregulate several factors in BeWo cells, including HIF-1 $[48,49]$ and downregulate factors such as syncytin $[44,50]$. We found PAPPA 2 mRNA levels were approximately 47 times higher when BeWo cells were grown under hypoxic conditions (Figure 1; Wilcoxon $\mathrm{Z}=2.506, \mathrm{p}=0.0122$ ). We confirmed that this differential expression was reflected in protein levels, and found an approximate $14 \%$ upregulation of PAPPA2 protein using in-cell Western staining. Western blotting did not detect PAPPA2 in the conditioned cell medium (data not shown), even though we were previously able to detect PAPPA2 in Western blots of murine and human tissue $[17,51]$. Our inability to measure secreted PAPPA2 may account for the difference in the magnitude of effect on

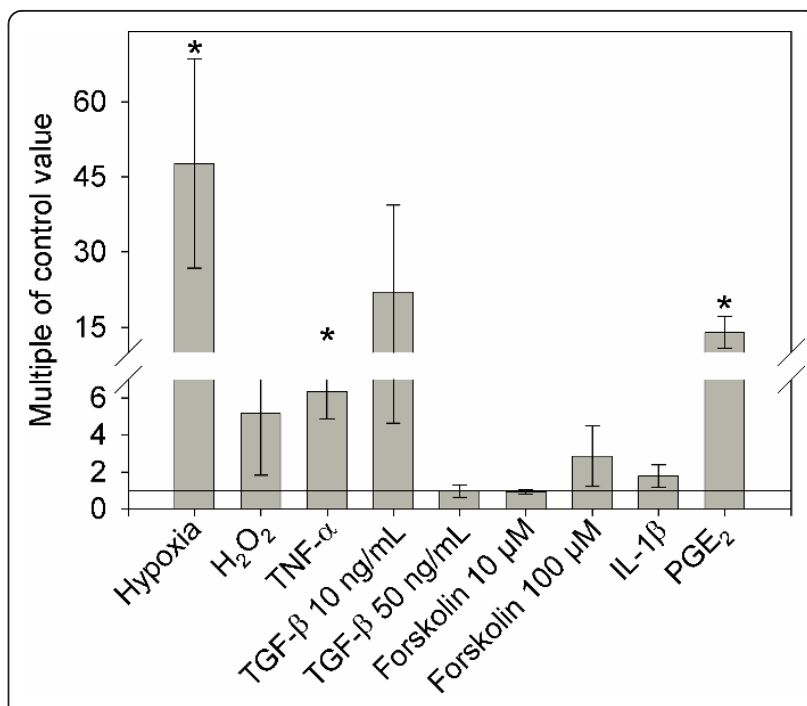

Figure 1 PAPPA2 mRNA expression in BeWo cells. PAPPA2 mRNA levels are expressed as fold change compared to control ( $0.1 \%$ ethanol was used as a control for forskolin). Cells were treated for 24 hours with $10 \mu \mathrm{M}$ forskolin, $100 \mu \mathrm{M}$ forskolin, $20 \mu \mathrm{M} \mathrm{H} \mathrm{H}_{2}$, $2 \% \mathrm{O}_{2}$ (hypoxia), $100 \mathrm{ng} / \mathrm{mL} \mathrm{IL}-1 \beta, 1 \mu \mathrm{M} \mathrm{PGE}, 10 \mathrm{ng} / \mathrm{mL}$ TGF- $\beta, 50$ $\mathrm{ng} / \mathrm{mL}$ TGF- $\beta$, and $100 \mathrm{ng} / \mathrm{mL}$ TNF- $\alpha, \mathrm{N}=5$. Columns with an asterisk $\left(^{*}\right)$ indicate expression significantly different from the control $(p<0.05)$. Although the mean $10 \mathrm{ng} / \mathrm{mL}$ TGF- $\beta$ expression is high, only one of the five replicates showed high expression levels relative to controls.

mRNA and protein expression. Hypoxia had no significant effect on either PAPPA (Wilcoxon $\mathrm{Z}=0.4178, \mathrm{p}=$ 0.6761) or ADAM12 (Wilcoxon $Z=0, p=1$ ) expression. Impaired trophoblast invasion into the maternal decidua is thought to cause decreased and intermittent blood flow to the placenta $[25,28,52]$, with reperfusion leading to an increase in reactive oxygen species with potentially damaging effects. A previous study found that addition of reactive oxygen species, specifically hydrogen peroxide at high levels $(50 \mathrm{uM})$ caused an increase in apoptosis in BeWo cells [29]. We therefore used a lower $\mathrm{H}_{2} \mathrm{O}_{2}$ concentration $(20 \mathrm{uM})$ to mimic reperfusion injury and did not find any effect on PAPPA2 mRNA expression after 24 hours (Figure 1; Wilcoxon $\mathrm{Z}=0.417, \mathrm{p}=0.6761$ ).

\section{Factors that affect syncytialization}

TNF- $\alpha$ has been shown to impair syncytialization, based on impaired expression of hCG [53]. TNF- $\alpha$ expression has also been shown to increase in preeclamptic pregnancies at delivery [54] and in response to hypoxia/reoxygenation conditions [55]. Treating cells with $100 \mathrm{ng} / \mathrm{mL}$ TNF- $\alpha$ resulted in 6.34 times higher PAPPA2 expression (Figure 1; Wilcoxon $\mathrm{Z}=2.507, \mathrm{p}=0.0122$ ). This upregulation was confirmed using in-cell Western analysis, where we found an $18 \%$ upregulation in PAPPA2 protein expression compared to controls. Once again, our inability to detect free PAPPA2 in cell medium may account for the 
lower upregulation at the protein level. PAPPA $(Z=0.627$, $\mathrm{p}=0.5309)$ and ADAM12 $(\mathrm{Z}=0.209, \mathrm{p}=0.8345) \mathrm{mRNA}$ levels were not found to be affected by treatment with TNF- $\alpha$. TGF- $\beta$ has also been shown to inhibit trophoblast differentiation in human cytotrophoblast cells [56] perhaps due, in part, to its proposed tumor-suppressing activity [57]. We did not find any effect of $10 \mathrm{ng} / \mathrm{mL}$ TGF- $\beta$ or $50 \mathrm{ng} / \mathrm{mL}$ TGF- $\beta$ on PAPPA2 mRNA expression (Figure 1; Wilcoxon $\mathrm{Z}=0, \mathrm{p}=1$; Wilcoxon $\mathrm{Z}=0.2089 \mathrm{p}=0.8345$; respectively). Treatment with TGF- $\beta$ did not cause any significant increase in PAPPA $(10 \mathrm{ng} / \mathrm{mL}$ Wilcoxon $\mathrm{Z}=$ $-0.209, \mathrm{p}=0.8345 ; 50 \mathrm{ng} / \mathrm{mL} \mathrm{Z}=-0.418, \mathrm{p}=0.6761)$ or ADAM12 (10 ng/mL Wilcoxon $\mathrm{Z}=0, \mathrm{p}=1 ; 50 \mathrm{ng} / \mathrm{mL}$ $\mathrm{Z}=0, \mathrm{p}=1$ ) mRNA levels. Furthermore, we did not find any significant difference in E-cadherin expression, suggesting that neither TNF- $\alpha$ (Wilcoxon $Z=0.208, \mathrm{p}=$ $0.8345)$ nor TGF- $\beta$ (10 ng/mL Wilcoxon $Z=0.626, \mathrm{p}=$ $0.5309 ; 50 \mathrm{ng} / \mathrm{mL} \mathrm{Z}=-0.418, \mathrm{p}=0.6761$ ) changed the rate of syncytialization.

Forskolin has been shown to increase intracellular cAMP levels and trigger increased cellular fusion in BeWo cells [30]. Surprisingly, we did not detect a significant decrease in E-cadherin mRNA compared to the $0.1 \%$ ethanol vehicle control $(10 \mu \mathrm{M}$ : Wilcoxon $\mathrm{Z}=-1.880, \mathrm{p}=$ 0.0601; $100 \mu \mathrm{M}$ : Wilcoxon $\mathrm{Z}=-1.462, \mathrm{p}=0.1437)$, and so did not find significant evidence of syncytialization in response to forskolin treatment. However, previous studies have shown that forskolin treatment at both $10 \mu \mathrm{M}$ [57] and $100 \mu \mathrm{M}[30,32,44,58]$ does induce cell fusion, based on other measurements of syncytialization such as levels of syncytin and human chorionic gonadotropin (hCG). We did not find any significant effect of either $10 \mu \mathrm{M}$ or $100 \mu \mathrm{M}$ of forskolin on PAPPA2 expression (Figure 1; Wilcoxon $\mathrm{Z}=0.418, \mathrm{p}=0.6761$ in both cases).

\section{Factors known to upregulate PAPPA}

A previous study by Conover et al. [33] tested the effect of various growth factors on PAPPA expression in osteoblasts, finding that TGF- $\beta$, TNF- $\alpha$, IL- $1 \beta$ or $\mathrm{PGE}_{2}$ all increased PAPPA mRNA and protein expression. As we described above, in BeWo cells TGF- $\beta$ had no effect on PAPPA2 expression, but TNF- $\alpha$ caused a significant upregulation in both mRNA and protein. Treating BeWo cells with $100 \mathrm{ng} / \mathrm{mL}$ IL-1 $\beta$ did not have a significant effect on PAPPA2 mRNA expression (Figure 1; Wilcoxon $Z=1.462$, $\mathrm{p}=0.1437$ ). In preeclamptic pregnancies, $\mathrm{PGE}_{2}$ levels increase in placental tissue at term [59], and we found that treatment with $1 \mu \mathrm{M} \mathrm{PGE}_{2}$ resulted in a 14-fold upregulation of PAPPA2 mRNA levels (Figure 1; Wilcoxon $\mathrm{Z}=$ 2.507, $\mathrm{p}=0.0122$ ). However, we were not able to confirm PAPPA2 protein upregulation using the in-cell Western assay. Furthermore, PAPPA and ADAM12 were not affected by any of these factors, including PGE2 ( $\mathrm{Z}=$ $-1.6712, \mathrm{p}=0.0947 ; \mathrm{Z}=-1.6712, \mathrm{p}=0.0947$; respectively).

\section{Conclusions}

Our study demonstrated that factors highly expressed in preeclamptic patients, PGE $_{2}$ and TNF- $\alpha[54,59]$, increase the expression of PAPPA2, at least at the mRNA level, suggesting a potential mechanism underlying the elevated PAPPA2 levels in preeclamptic placentae at term [9,11-14]. Hypoxia, a condition known to occur in preeclamptic placentae [10], was also shown to increase PAPPA2 expression. However, these same treatments had no effect on two other IGFBP proteases, PAPPA and ADAM12. We have previously demonstrated that differences in placental PAPPA2 expression do not result in significant changes in placental or birth weight in mice [51]. Both these previous results and those of the present study are consistent with the hypothesis that PAPPA2 is upregulated as a consequence of placental pathology, rather than elevated PAPPA2 levels being a cause of abnormal placental development and preeclampsia.

\section{Abbreviations}

ADAM12: A disintegrin and metalloproteinase 12; GAPDH: glyceraldehyde 3-phosphate dehydrogenase; HELLP: hemolytic anemia, elevated liver enzymes, and low platelet count; IGF: insulin-like growth factor; IGFBP: insulin-like growth factor-binding protein; IL-1ß: interleukin-1beta; IUGR: intrauterine growth restriction; qRT-PCR: quantitative real-time polymerase chain reaction; QTL: quantitative trait locus; PAPPA: pregnancy-associated plasma protein $A$; PAPPA2: pregnancy-associated plasma protein $A 2 ; P_{2} E_{2}$ : prostaglandin $\mathrm{E}_{2}$; ROS: reactive oxygen species; TGF- $\beta$ : Transforming Growth Factor-beta; TNF-a: tumor necrosis factor-alpha.

\section{Acknowledgements}

We thank Gordon Rintoul, Audrey Speelman, Bryce Pasqualotto, and Tim Beischlag for technical support and the use of their equipment, Dan Rurak and Gratien Prefontaine for providing input into study design, and Andrée Gruslin and Qing Qiu for the gift of BeWo cells. This study was funded by a Natural Sciences and Engineering Research Council (NSERC) operating grant and a Simon Fraser University (SFU) President's Research Grant to JKC, a Canadian Institutes of Health Research (CIHR) Master's award to PKW, and a SFU Vice President of Research Undergraduate Student Research Award to AO.

\section{Authors' contributions}

PKW participated in the design of the study, carried out most of the experimental work and drafted the manuscript. AO performed the RNA extraction and qRT-PCR. JKC conceived of the study, participated in its design and helped to draft the manuscript. All authors read and approved the final manuscript.

\section{Competing interests}

The authors declare that they have no competing interests.

Received: 10 February 2011 Accepted: 15 April 2011

Published: 15 April 2011

\section{References}

1. Cross JC: The genetics of pre-eclampsia: a feto-placental or maternal problem? Clin Genet 2003, 64:96-103.

2. von Dadelszen P, Menzies JM, Payne B, Magee LA, PIERS (Preeclampsia Integrated Estimate of RiSk) Study Group: Predicting adverse outcomes in women with severe pre-eclampsia. Semin Perinatol 2009, 33:152-157.

3. Johnson MP, Fitzpatrick E, Dyer TD, Jowett JBM, Brennecke SP, Blangero J, Moses EK: Identification of two novel quantitative trait loci for preeclampsia susceptibility on chromosomes $5 q$ and $13 q$ using a variance components-based linkage approach. Mol Hum Reprod 2007, 13:61-67. 
4. Sibai BM, Ewell M, Levine RJ, Klebanoff MA, Esterlitz J, Catalano PM, Goldenberg RL, Joffe G: Risk factors associated with preeclampsia in healthy nulliparous women. Am J Obstet Gynecol 1997, 177:1003-1010.

5. von Dadelszen $P$, Magee $L$ : What matters in preeclampsia are the associated adverse outcomes: the view from Canada. Curr Opin Obstet Gynecol 2008, 20:110-115.

6. Gauster M, Moser G, Orendi K, Huppertz B: Factors involved in regulating trophoblast fusion: potential role in the development of preeclampsia. Placenta 2009, 30(Suppl A):S49-54.

7. Kaufmann P, Black S, Huppertz B: Endovascular trophoblast invasion: implications for the pathogenesis of intrauterine growth retardation and preeclampsia. Biol Reprod 2003, 69:1-7.

8. Huang SJ, Chen C, Schatz F, Rahman M, Abrahams VM, Lockwood CJ: Preeclampsia is associated with dendritic cell recruitment into the uterine decidua. J Pathol 2008, 214:328-336.

9. Sitras V, Paulssen RH, Grønaas H, Leirvik J, Hanssen TA, Vårtun A, Acharya G: Differential placental gene expression in severe preeclampsia. Placenta 2009, 30:424-433.

10. Lachmeijer AMA, Dekker GA, Pals G, Aarnoudse JG, ten Kate LP, Arngrimsson R: Searching for preeclampsia genes: the current position. Eur J Obstet Gyn R B 2002, 105:94-113.

11. Buimer $M$, Keijser $R$, Jebbink JM, Wehkamp D, van Kampen AH, Boer $K$, van der Post JA, Ris-Stalpers C: Seven placental transcripts characterize HELLPsyndrome. Placenta 2008, 29:444-453.

12. Nishizawa $H$, Pryor-Koishi K, Suzuki M, Kato T, Kogo H, Sekiya T, Kurahashi $H$ Udagawa Y: Increased levels of pregnancy-associated plasma protein-A2 in the serum of pre-eclamptic patients. Mol Hum Reprod 2008, 14:595-602.

13. Varkonyi T, Schoenleber J, Nagy B, Fuele T, Tarca AL, Karaszi K, Schoenleber J, Hupuczi P, Mihalik N, Kovalszky I, Rigo J Jr, Meiri H, Papp Z, Romero R, Than NG: Microarray Profiling Reveals That Placental Transcriptomes of Early-onset HELLP Syndrome and Preeclampsia Are Similar. Placenta 2011, 32:S21-S29.

14. Winn VD, Gormley M, Paquet AC, Kjar-Sorensen K, Kramer A, Rumer KK, Haimov-Kochman R, Yeh RF, Overgaard MT, Varki A, Oxvig C, Fisher SJ: Severe preeclampsia-related changes in gene expression at the maternal-fetal interface include siglec- 6 and pappalysin-2. Endocrinology 2008, 150:452-462.

15. Overgaard MT, Boldt HB, Laursen LS, Sottrup-Jensen L, Conover CA, Oxvig C: Pregnancy-associated plasma protein-A2 (PAPP-A2), a novel insulin-like growth factor-binding protein-5 proteinase. J Biol Chem 2001, 276:21849-21853.

16. Yan X, Baxter RC, Firth SM: Involvement of pregnancy-associated plasma protein-A2 in insulin-like growth factor (IGF) binding protein-5 proteolysis during pregnancy: a potential mechanism for increasing IGF bioavailability. J Clin Endocrinol Metab 2010, 95:1412-1420.

17. Wang J, Qiu Q, Haider M, Bell M, Gruslin A, Christians JK: Expression of pregnancy associated plasma protein A2 (PAPPA2) during pregnancy in human and mouse. J Endocrinol 2009, 202:337-345.

18. Christians JK, Gruslin A: Altered levels of insulin-like growth factor binding protein proteases in preeclampsia and intrauterine growth restriction. Prenat Diagn 2010, 30:815-820

19. Cowans NJ, Spencer K: First-trimester ADAM12 and PAPP-A as markers for intrauterine fetal growth restriction through their roles in the insulinlike growth factor system. Prenat Diagn 2007, 27:264-271.

20. Shi Z, Xu W, Loechel F, Wewer UM, Murphy L: ADAM 12, a disintegrin metalloprotease, interacts with insulin-like growth factor-binding protein-3. J Biol Chem 2000, 275:18574-18580.

21. Loechel F, Fox JW, Murphy G, Albrechtsen R, Wewer UM: ADAM 12-S cleaves IGFBP-3 and IGFBP-5 and is inhibited by TIMP-3. Biochem Bioph Res Co 2000, 278:511-515.

22. Laigaard J, Sorensen T, Placing S, Holck P, Frohlich C, Wojdemann KR, Sundberg K, Shalmi AC, Tabor A, Norgaard-Pedersen B, Ottesen B, Christiansen M, Wewer UM: Reduction of the disintegrin and metalloprotease ADAM12 in preeclampsia. Obstet Gynecol 2005, 106:144-149.

23. Spencer K, Cowans NJ, Stamatopoulou A: ADAM12s in maternal serum as a potential marker of pre-eclampsia. Prenat Diagn 2008, 28:212-216.

24. Miller R, Huppertz B: Human placental explants in culture: Approaches and assessments. Placenta 2005, 26:439-448

25. Hung TH, Skepper JN, Burton GJ: In vitro ischemia-reperfusion injury in term human placenta as a model for oxidative stress in pathological pregnancies. Am J Pathol 2001, 159:1031-1043.
26. Guzin K, Tomruk S, Tuncay YA, Naki M, Sezginsoy S, Zemheri E, Yucel N, Kanadikirik F: The relation of increased uterine artery blood flow resistance and impaired trophoblast invasion in pre-eclamptic pregnancies. Arch Gynecol Obstet 2005, 272:283-288.

27. Meekins JW, Pijnenborg R, Hanssens M, McFadyen IR, van Asshe A: A study of placental bed spiral arteries and trophoblast invasion in normal and severe pre-eclamptic pregnancies. Br J Obstet Gynaecol 1994, 101:669-674.

28. Hung TH, Skepper JN, Charnock-Jones DS, Burton GJ: Hypoxiareoxygenation: a potent inducer of apoptotic changes in the human placenta and possible etiological factor in preeclampsia. Circ Res 2002, 90:1274-1281.

29. Heazell AEP, Taylor NNJ, Greenwood SL, Baker PN, Crocker IP: Does altered oxygenation or reactive oxygen species alter cell turnover of BeWo choriocarcinoma cells? Reprod Biomed Online 2009, 18:111-119.

30. Kudo Y, Boyd CA, Kimura H, Cook PR, Redman CW, Sargent IL: Quantifying the syncytialisation of human placental trophoblast BeWo cells grown in vitro. BBA - Mol Cell Res 2003, 1640:25-31.

31. Knerr I, Schubert SW, Wich C, Amann K, Aigner T, Vogler T, Jung R, Dotsch J, Rascher W, Hashemolhosseini S: Stimulation of GCMa and syncytin via CAMP mediated PKA signaling in human trophoblastic cells under normoxic and hypoxic conditions. FEBS Lett 2005, 579:3991-3998.

32. Kudo Y, Boyd CA, Sargent IL, Redman CW, Lee JM, Freeman TC: An analysis using DNA microarray of the time course of gene expression during syncytialization of a human placental cell line (BeWo). Placenta 2004, 25:479-488.

33. Conover CA, Chen BK, Resch ZT: Regulation of pregnancy-associated plasma protein-A expression in cultured human osteoblasts. Bone 2004 34:297-302.

34. Ramos AJ, Cantero MR, Zhang P, Raychowdhury MK, Green A, MacPhee D, Cantiello HF: Morphological and electrical properties of human trophoblast choriocarcinoma, BeWo cells. Placenta 2008, 29:492-502.

35. King A, Thomas L, Bischof P: Cell culture models of trophoblast II: trophoblast cell lines-a workshop report. Placenta 2000, 21(Suppl A): S113-9.

36. Fialova L, Malbohan IM: Pregnancy-associated plasma protein A (PAPP-A): theoretical and clinical aspects. Bratisl Lek Listy 2002, 103:194-205.

37. Smith GC, Stenhouse EJ, Crossley JA, Aitken DA, Cameron AD, Connor JM: Early pregnancy levels of pregnancy-associated plasma protein a and the risk of intrauterine growth restriction, premature birth, preeclampsia, and stillbirth. J Clin Endocrinol Metab 2002, 87:1762-1767.

38. Bersinger NA, Smarason AK, Muttukrishna S, Groome NP, Redman CW: Women with preeclampsia have increased serum levels of pregnancyassociated plasma protein A (PAPP-A), inhibin A, activin A, and soluble E-selectin. Hyperten Pregnancy 2003, 22:45-55.

39. Valinen $Y$, Ryynanen M: Maternal serum ADAM12 levels correlate with PAPP-A levels during the first trimester. Gynecol Obstet Invest 2010, 70:60-63.

40. Coutifaris C, Kao LC, Sehdev HM, Chin U, Babalola GO, Blaschuk OW, Strauss JF: E-cadherin expression during the differentiation of human trophoblasts. Development 1991, 113:767-777.

41. Arimoto-Ishida E, Sakata M, Sawada K, Nakayama M, Nishimoto F, Mabuchi S, Takeda T, Yamamoto T, Isobe A, Okamoto Y, Lengyel E, Suehara N, Morishige K, Kimura T: Up-regulation of alpha(5)-integrin by $\mathrm{E}$-cadherin loss in hypoxia and its key role in the migration of extravillous trophoblast cells during early implantation. Endocrinology 2009, 150:4306-4315

42. Rytting E, Audus KL: Effects of low oxygen levels on the expression and function of transporter OCTN2 in BeWo cells. J Pharm Pharmacol 2007, 59:1095-1102.

43. Barbosa B, Ferro E: Bewo trophoblast cell susceptibility to Toxoplasma gondii is increased by interleukin-10 and transforming growth factorbeta 1. Placenta 2008, 29:130-130.

44. Kudo Y, Boyd CA, Sargent IL, Redman CW: Hypoxia alters expression and function of syncytin and its receptor during trophoblast cell fusion of human placental BeWo cells: implications for impaired trophoblast syncytialisation in pre-eclampsia. BBA - Mol Basis Dis 2003, 1638:63-71.

45. Egorina E, Sovershaev MA, Osterud B: In-Cell Western assay: a new approach to visualize tissue factor in human monocytes. J Thromb Haemost 2006, 4:614-620.

46. Pfaffl MW: A new mathematical model for relative quantification in realtime RT-PCR. Nucleic Acids Res 2001, 29:e45. 
47. Graven K, Farber H: Hypoxic regulation of endothelial glyceraldehyde-3phosphate dehydrogenase. Am J Physiol - Cell Ph 1998, 274:C347-C355.

48. Hayashi M, Sakata M, Takeda T, Tahara M, Yamamoto T, Okamoto Y, Minekawa R, Isobe A, Ohmichi M, Tasaka K, Murata Y: Up-regulation of c-met protooncogene product expression through hypoxia-inducible factor-1 alpha is involved in trophoblast invasion under low-oxygen tension. Endocrinology 2005, 146:4682-4689.

49. Baumann MU, Zamudio S, Illsley NP: Hypoxic upregulation of glucose transporters in BeWo choriocarcinoma cells is mediated by hypoxiainducible factor-1. Am J Physiol - Cell Ph 2007, 293:C477-C485.

50. Knerr I, Weigel C, Linnemann K, Dotsch J, Meissner U, Fusch C, Rascher W: Transcriptional effects of hypoxia on fusiogenic syncytin and its receptor ASCT2 in human cytotrophoblast BeWo cells and in ex vivo perfused placental cotyledons. Am J Obstet Gynecol 2003, 189:583-588.

51. Wagner PK, Christians JK: Altered placental expression of PAPPA2 does not affect birth weight in mice. Reprod Biol Endocrin 2010, 8:90.

52. Collard CD, Gelman S: Pathophysiology, clinical manifestations, and prevention of ischemia-reperfusion injury. Anesthesiology 2001, 94:1133-1138.

53. Leisser C, Knofler M: Tumour necrosis factor-alpha impairs chorionic gonadotrophin beta-subunit expression and cell fusion of human villous cytotrophoblast. Mol Hum Reprod 2006, 12:601-609.

54. Wang $Y$, Walsh S: TNF alpha concentrations and mRNA expression are increased in preeclamptic placentas. J Reprod Immunol 1996, 32:157-169.

55. Hung TH, Charnock-Jones DS, Skepper JN, Burton GJ: Secretion of tumor necrosis factor-alpha from human placental tissues induced by hypoxiareoxygenation causes endothelial cell activation in vitro: a potential mediator of the inflammatory response in preeclampsia. Am J Pathol 2004, 164:1049-1061.

56. Morrish D, Paras M: Transforming growth factor-beta- 1 inhibits placental differentiation and human chorionic-gonadotropin and human placental-lactogen secretion. Endocrinology 1991, 129:22-26.

57. Rama S, Rao A: Regulation of telomerase during human placental differentiation: a role for TGF beta 1. Mol Cell Endocrinol 2001, 182:233-248

58. Cohran V, Fang J, Milio L, Smith CH, Fant M: Type I insulin-like growth factor receptors in the BeWo choriocarcinoma cell (b30 clone) during cell differentiation. Placenta 1996, 17:313-320.

59. Munno I, Chiechi LM, Lacedra G, Putignano G, Patimo C, Lobascio A, Loizzi P: Spontaneous and induced release of prostaglandins, interleukin (IL)-1beta, IL-6, and tumor necrosis factor-alpha by placental tissue from normal and preeclamptic pregnancies. Am I Reprod Immunol 1999, 42:369-374.

doi:10.1186/1477-7827-9-48

Cite this article as: Wagner et al:: Regulation of pregnancy-associated plasma protein A2 (PAPPA2) in a human placental trophoblast cell line (BeWo). Reproductive Biology and Endocrinology 2011 9:48.

\section{Submit your next manuscript to BioMed Central and take full advantage of:}

- Convenient online submission

- Thorough peer review

- No space constraints or color figure charges

- Immediate publication on acceptance

- Inclusion in PubMed, CAS, Scopus and Google Scholar

- Research which is freely available for redistribution

Submit your manuscript at www.biomedcentral.com/submit
Biomed Central 